\title{
The biological potency of benzapyrene in the humates composition
}

\author{
L. I. Belykh, I. A. Ryabchikova, S. S. Timofeyeva
}

Irkutsk State Technical University, Irkutsk, Russia; $\underline{\text { bgd@istu.edu }}$

Received 25 June 2013; revised 2 November 2013; accepted 17 November 2013

Copyright (C) 2013 L. I. Belykh et al. This is an open access article distributed under the Creative Commons Attribution License, which permits unrestricted use, distribution, and reproduction in any medium, provided the original work is properly cited.

\section{ABSTRACT}

The aim of the paper was to determine ben$z(a)$-pyrene in the preparations containing humates and study the benz(a)pyrene biological potency for the agricultural plants. The research methodology included the determination of the dependencies in the system "substance concentration (dose)-effect on the plant". Concentrations of benz(a)pyrene in 12 samples of the humates preparations and fertilizers based on their trademarks "Irkutsk humates", obtained from brown coal, varied in the range from 0.3 to 50 $\mathrm{mcg} / \mathrm{kg}$, which creates no soil contamination in conditions of the use of preparations. Between contents of benz(a)pyrene and humates there is a correlation $\left(r_{x y}=0.95 ; \alpha=0.05\right)$. It is ascertained that the effects of stimulation and/or inhibition of the growth and yield of agricultural plants depend on the concentration of ben$z(a) p y r e n e$ and the method of plant processing. Optimal concentrations of benz(a)pyrene were $150-200 \mathrm{ng} / \mathrm{dm}^{3}$ for preplant way of processing of potato tubers, $3-10 \mathrm{ng} / \mathrm{dm}^{3}$ - for top dressing (spraying) and $0.1-0.3 \mathrm{ng} / \mathrm{dm}^{3}$ - for dressing under the roots (hydroponic). The obtained results allowed us to offer one of the possible mechanisms of biological potency of humates as the plant growth stimulants, and also a way testing of the preparations by screening of their benz(a)pyrene content.

Keywords: Polycyclic Aromatic Hydrocarbons; Benz(a)pyrene; Preparations and Fertilizers Containing Humates; Biological Potency Defining Method

\section{INTRODUCTION}

Humates are sodium or/and potassium salts of the hu- mic acids. They are extracted from the humic substances of the organic formations like chernozem, peat, coal, sapropel, shale and so on. Humates enter into the composition of the preparations and fertilizers based on them, which are widely used in raising the crop capacity of field and green crops as well as their diseases, drought and frost resistance $[1,2]$.

The humates effect exhibits the stimulation of plants growth, their crop capacity, resistance and other effects when the concentration of the preparations is very low in $0.01 \%-0.03 \%$ water solutions [1]. They are usually made experimentally with different additions selecting the conditions of the practical application. For example, the composition and the components accompanying the humates, the doses added and agricultural objects processing technologies (seeds, buds, soils) are taken into account. The detailed study of all conditions of the preparations use depends on the fact that the humates can produce, besides stimulating effects, inhibition. The labor-consuming and cost-based empirical approach of the efficient humates application is conditioned by the lack of knowledge on how they affect different functions of the living organisms. One of the mechanisms of the humates biological potency is the effect on the active organic compounds being part of their content like carbanils, carboxyls, phenolic hydroxyls and nitrogen substituted aromatic groups as well as polycyclic aromatic hydrocarbons (PAHs). They have broad spectrum biological potency (carcinogenesis, mutagenesis, teratogenesis, toxicity and others) and, in practice, can always be found in the natural organic masses [3-6]. Among the PAHs the indicative benz(a)pyrene $(\mathrm{BaP})$ is distinguished by being notable for its high carcinogenic activity (the $1^{\text {st }}$ class of hazard). That is why the $\mathrm{BaP}$ control of the preparations based on the humates, often used as a plant growth stimulant, is very necessary.

The aim of the paper is to analyze the $\mathrm{BaP}$ content of the humates preparations and fertilizers based on them named "Irkutsk humates" and study the $\mathrm{BaP}$ biological 
potency for the agriculture of various methods of treatment.

\section{EXPLORATORY PROCEDURE}

The study subject is 12 samples of the humates preparations and fertilizers based on them of different trade marks of "Irkutsk humates" made by "Gumat" Agrarian Technologies Co Ltd (Irkutsk, Russia). The preparations were obtained by the authors work [1,2] from highly oxidized low-ash carbons $(25 \%$ - $50 \%$ of ashy part is mostly presented by silica, aluminum silicates, calcium and magnesium salts) of the Cheremkhovo coal basin treating the raw materials with weak solutions of alkali followed by purifying of the extracts. The ready initial humates preparations contained high contents of sodium and/or potassium salts of humic acids $(60 \%-80 \%)$, included fulvic acids salts $(5 \%-8 \%)$, general silicon $(8 \%$ $9 \%)$ and water-soluable one (3\% - 4\%), carbon components $(66 \%)$, oxygen (26\%), hydrogen (up to $5 \%$ ), sodium $(3 \%-4 \%)$, potassium $(4 \%-6 \%)$, sulphur (up to $1 \%)$, phosphorus $(0.4 \%)$ as well as macro- and microelements [1]. The very low content of lead $(0.003 \%)$, the lack of mercury and cadmium eliminate the problem of the toxicity of heavy metals using the preparations.

On the bases of the obtained humates different fertilizers with the addition of microelements, urea, superphosphate and some other bulkier materials are made $[1,2]$. The study of their application revealed the effects of physiological activity both in plant growing and animal husbandry at a very low concentration of the humates about $0.001 \%-0.03 \%$. At a high substance concentration, the effects of plant growth depression were often observed.

The $\mathrm{BaP}$ testing in the preparations was carried out according to the devised and assessed methodology [7]. From the preparation specimens weighing $1.00-20.0 \mathrm{~g}$ the $\mathrm{BaP}$ was got by the method of ultrasonic extraction with the mixture of the refined dissolvents n-hexane: chloroform (1:1). The extracts were filtered off the solid phase and concentrated under the vacuum. From the concentrate some interfering organic components (humic substances, plant pigment, accompanying PAH) were removed by means of chromatographic fractionation with the releasing of $\mathrm{BaP}$ containing fraction using the method of thin-layer or column chromatography on the activated layer of aluminum oxide in the system of n-hexane: chloroform (9:1) followed by the elution of a defined component with the help of the mixture of benzol:acetone $(1: 1)$. The $\mathrm{BaP}$ mass concentration was estimated with the help of the method of low-temperature luminescence using the fluorescence spectrometer "Hitachi 650-10 S" (Japan) in the solution of n-octane. The methodology makes it possible to get the results of the measurement with a relative resultant error from $60 \%$ to $22 \%$ accordingly in the range of the substance concentration from 0.5 to $2500 \mathrm{mcg} / \mathrm{kg}$ of the preparation with the confidence coefficient $P=95 \%$ and the detection limit equal to $0.05 \mathrm{mcg} / \mathrm{kg}$. The correlation coefficient $\left(r_{x y}\right)$ was calculated by the program estimating the tabular significance level $(\alpha)$ according to the double-ended criterion.

\section{RESULTS And DISCUSSION}

The BaP content level in all of the tested preparations "Irkutsk humates" depended on their composition (Table 1). The maximum concentration of the compound was found in the initial mixed sample of different brands of the processed coal named "GUMAT". On its basis some other mixtures of various preparations were made in those the $\mathrm{BaP}$ content was reduced and varied from 0.3 to $25 \mathrm{mcg} / \mathrm{kg}$. These concentrations coincide with those ones in the soils of different types of background regions $(0.1-17.6 \mathrm{mcg} / \mathrm{kg})$, at the same time the content of carcinogen in the initial preparation comparable with its level in the brown coal of the Beryozovskoe field ( 75 $\mathrm{mcg} / \mathrm{kg}$ ) [3-6]. The humic acids extracted from the humic substances of the natural organic formations are dressed with aromatic structures [2]. In their composition there may be PAH including BaP that, as our results show, is found in all the preparations named "Irkutsk humates". Its concentration, except the sample of "GUMAT", does not exceed the maximum permissible concentration of $\mathrm{BaP}$ in the soils [6]. Taking into consideration the fact that the preparations are applied into the soils in small content (less than $0.03 \%-0.5 \%$ ), all of them are safe in terms of the possibility of soils contamination by a carcinogenic substance.

The BaP presence in the tested preparations (Table 1) can be the result of both the decomposition reactions of the compound aromatic structures of humic acids and humates and their hydrophobic bonds with endogenous or exogenous PAH. The evidence of the latter is the direct dependence of the $\mathrm{BaP}$ concentration of the tested samples on the content of the salts of the humic acids (Table 2). Between the concentration of the above-mentioned components there is linear positive correlation with the coefficient $r_{x y}=0.952(\alpha<0.05)$. It is likely that $\mathrm{BaP}$ has hydrophobic binding with humates aromatic structures extracted from coal. As it follows from the analysis of the obtained results and well-known researches in the literature, in the humates preparations got from the organic substances there is $\mathrm{BaP}$ and its concentration is connected with the content level of the salts of the humic acids.

The biological potency of $\mathrm{BaP}$ in the composition of the humates preparations to the plants was studied determining the dependence of " $\mathrm{BaP}$ concentration in a preparation-effect". It should be noted that obtaining, laboratory and field investigation of "Irkutsk humates" has 
Table 1. The content of benz(a)pyrene in "Irkutsk humates" preparations.

\begin{tabular}{|c|c|c|}
\hline No & Humates preparations and fertilizers on their basis & BaP concentration, $\mathrm{mcg} / \mathrm{kg}$ \\
\hline 1) & Fertilizer on the basis of humic acids: "GUMAT" (the mixed sample of A, B, V, G, C brands) & $50 \pm 20^{*}$ \\
\hline 2) & Fertilizer on the basis of humic acids with microelements: "GUMAT +7 " (the mixed sample of A and C brands) & $25 \pm 9$ \\
\hline 3) & Fertilizer on the basis of humic acids with microelements: "GUMAT +7 " ( $\mathrm{B}$ brand) & $25 \pm 9$ \\
\hline 4) & Microfertilizer "ZOLUSHKA" (the mixed sample of A and B brands) & $6.0 \pm 2.2$ \\
\hline 5) & Microfertilizer "BULBA" (the mixed sample of A and B brands) & $2.0 \pm 1.0$ \\
\hline 6) & Complex organic and mineral fertilizer "GUMAT-UNIVERSAL" (the mixed sample of A and B brands) & $12 \pm 4$ \\
\hline 7) & Complex organic and mineral fertilizer "GUMAT-UNIVERSAL" (the mixed sample of B and C brands) & $0.3 \pm 0.2$ \\
\hline 8) & Soil humated deoxidizer & $0.5 \pm 0.3$ \\
\hline 9) & Perlite drainage & $1.0 \pm 0.5$ \\
\hline 10) & Humated superphosphate & $1.5 \pm 0.7$ \\
\hline 11) & Humated carbamide (urea) & $1.2 \pm 0.7$ \\
\hline 12) & "GUMAT-80" & $3.0 \pm 1.5$ \\
\hline
\end{tabular}

${ }^{*}$ Mass concentration \pm result error of identifying, confidence probability $P=95 \%$.

Table 2. The content of benz(a)pyrene and humic acids salts in the structure of "Irkutsk humates" preparations.

\begin{tabular}{ccc}
\hline \multirow{2}{*}{ Fertilizer } & \multicolumn{2}{c}{ Mass concentration } \\
\cline { 2 - 3 } & $\mathbf{B}(\mathbf{a}) \mathbf{P}, \mathbf{m c g} / \mathbf{k g}$ & Humic acids salts, \% \\
\hline "GUMAT" (a mixed sample) & $50 \pm 20$ & 79 \\
"GUMAT + 7" & $25 \pm 9$ & 63 \\
"ZOLUSHKA" & $6.0 \pm 2.2$ & 10 \\
"BULBA" & $2.0 \pm 1.0$ & 3.5 \\
\hline
\end{tabular}

been carried out with large breaks since the 60-s of the last century in many establishments. The performance of the humates has been studied both for different vegetable agriculture (wheat, barley, potato plants, pea and others) and animal husbandry or poultry farming [1,2]. In all cases positive growth effects, crop capacity increase, organisms resistance rise are got. The peculiarity of such researches is an experimental selecting of humates practical application conditions, strict procedures of the preparations use and plants cultivation. This is also the technology of fertilizers obtaining, their testing in different conditions of dressing in the form of solutions, seeds treatment, applying to soils. Such empirical approaches, to a considerable degree, relate to the lack of knowledge of the humates action mechanism, possibly, as a result of its ambiguity.

The different conditions of humates application have been studied on cultivating vegetable agriculture $[1,2]$. One of the methods consists in the treatment of potato tubers of "Volzhanka" breed with the help of the water solution with the different content of "GUMAT" when the seeds are moving along the conveyor sorting line. The processing technology has been employed in autumn and spring with the fluid consumption of $9-10 \mathrm{dm}^{3}$ per 1 tonne of tubers. In the preparation water solutions in operation $\mathrm{BaP}$ concentrations have been calculated. The results of their influence on potato crop capacity increase are shown in Figure 1. In this figure and another figure depict the comparisons of the obtained by us identifications of $\mathrm{BaP}$ in the preparations which were tested as the stimulators of growth and raising the crop capacity of agricultural plants in the field conditions by other researchers $[1,2]$. One can see that within the range of the compound content of $0-150 \mathrm{ng} / \mathrm{dm}^{3}$ the increase of the tubers biomass directly depends on the concentration of $\mathrm{BaP}$ and increasing the biomass up to $200 \mathrm{ng} / \mathrm{dm}^{3}$ the effect stabilizes. Obviously, the observable dependence becomes apparent for the humate concentration that, as it has been shown above, is linearly related to $\mathrm{BaP}$ content.

Another example of such a relation is the method of top dressing (spraying the top part of the plant with the solution) of the carrot of "Nantskaya" kind with the water solutions of different content of "GUMAT" preparation (mixed sample) (Figure 2), also there is another example of treating the roots of wheat and pea, vegetable cells (dressing under the roots) in the model experiment (Figure 3). The result of all obtained relations is as follows: there is a defined range of $\mathrm{BaP}$ content providing the maximum effect of the yield gain, or roots and the plant cells. Meanwhile, increasing the content of actively operating humates and $\mathrm{BaP}$ the intensity of the effect stabilizes or even goes down. 


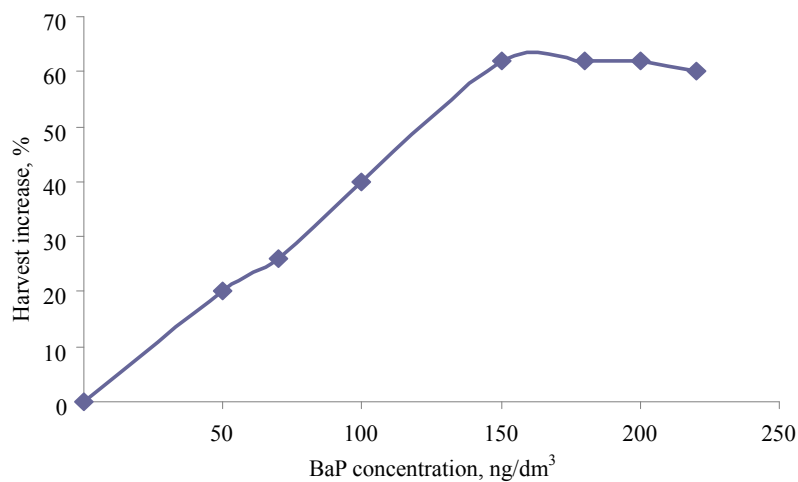

Figure 1. The influence of "GUMAT" preparation (a mixed sample) and benz(a)pyrene in its content on the productivity of "Volzhanka" potato brand during preplant tuber treatment with solutions.

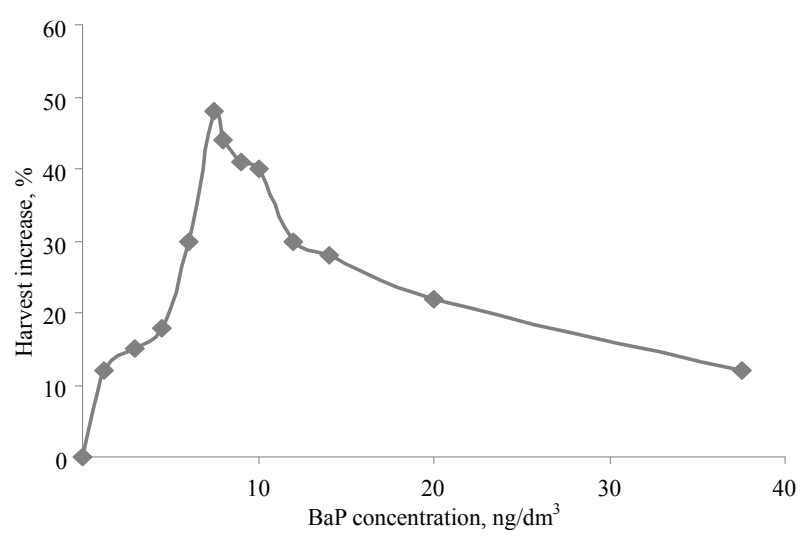

Figure 2. The influence of different concentrations of "GUMAT" preparation and benz(a)pyrene in its content on the productivity of "Nantskaya" carrot brand according to control (without preparation) using top dressing (spraying).

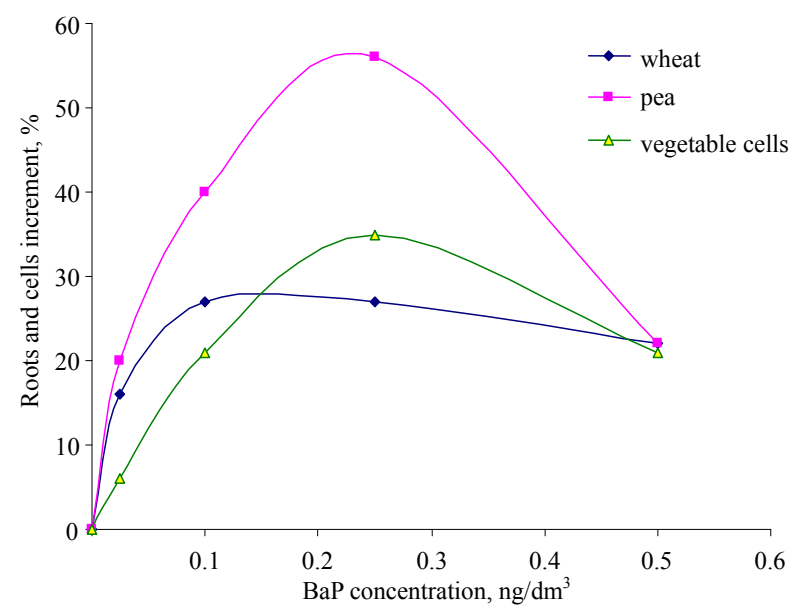

Figure 3. The influence of different concentrations of "GUMAT" preparation and benz(a)pyrene in its content on the roots growth of wheat $(\bullet)$, pea $(\mathbf{\square})$ and vegetable cells $(\boldsymbol{\Delta})$ using root additional fertilizing.

Under various conditions the similar content of different preparations were tested. They were considerably different among themselves according to the concentration of BaP. In this way, having one-time top dressing of "Nevsky" potato breed with water solutions of different concentration and preparations the stable increase of tubers productivity adding $\mathrm{BaP}$ concentration could be observed (Table 3). In this case, in spite of testing the fertilizers of different chemical composition there has been direct relation between potato crop capacity and $\mathrm{BaP}$ content in the solutions. The effect of stabilization has not become apparent. This can be explained by low content of a stimulant (up to $10 \mathrm{ng} / \mathrm{dm}^{3}$ ) comparing to the above considered conditions in Figure 2. Similar to the observed effects, the regular occurrence of the addition of the potato crop capacity of "Irtysh" kind treated by different preparations during the period of vegetation mass intensive growing (bud-formation period) was observed. Increasing the BaP load on the soil up to 10 $\mathrm{ng} / \mathrm{m}^{2}$ a sharp direct line of harvest increase followed by low effect decrease (up to $2 \%$ - 4\%) (Table 4).

The discussed examples reveal the influence of $\mathrm{BaP}$ concentration in the composition of "Irkutsk humates" preparations on the growth stimulation or harvest increase of different vegetable agriculture according to some general relationships: the availability of such a range of compound concentration that at low values show the increase effect followed by the stabilization or even decrease of the effect at high concentration.

In Table 5, the ranges of $\mathrm{BaP}$ concentration in the composition of the different preparations depending on the way of plant treatment are systemized stimulating the growth and productivity of the agriculture. From the range of effectively acting concentrations one can single out the most optimal one which can be recommended for the practical application. The calculation of the preparation amount necessary to the application in this or that way of processing providing the optimal acting concentration of $\mathrm{BaP}$ in a process solution can be done according to the formula:

$$
C_{\text {hum }}=\frac{C_{B P o p t}}{C_{B P_{\text {hum }}}},
$$

where $C_{\text {hum }}$ is the quantity of the ready for the application preparation, $\mathrm{g} / \mathrm{dm}^{3} ; C_{B P \text { Pot }}$ is the recommended optimal concentration of $\mathrm{BaP}$ in a preparation, $\mathrm{ng} / \mathrm{dm}^{3}$ (Table 5); $C_{B P h u m}$ is the concentration of $\mathrm{BaP}$ in a preparation, $\mathrm{ng} / \mathrm{g}$ (or $\mathrm{mcg} / \mathrm{kg}$ ).

After the calculation and weighting of the necessary amount of the preparation a water process solution is prepared and then the plants are treated according to the chosen way of processing. Meanwhile, the process solution needs to be prepared straight before its application and stored not more than 6 hours (storing humates water solutions BaP of low concentration can oxidize). In Table 6 the examples of calculation of probable preparation 
Table 3. The influence of different preparations, fertilizers and benz(a)pyrene on the crop capacity of "Nevsky" potato brand using the method of top dressing (spraying).

\begin{tabular}{ccc}
\hline Fertilizer and its content & Concentration B(a)P, $\mathbf{n g} / \mathbf{d m}^{\mathbf{3}}$ & Harvest, c/h (increase, \%) \\
\hline Without "GUMAT" (check) & lack & $244(0)$ \\
0.03\% "GUMAT-80" solution & 0.9 & $279(14)$ \\
$0.03 \%$ "GUMAT+7" ("GUMEL") solution & 7.5 & $292(20)$ \\
$0.03 \%$ "GUMAT + 7" solution & 7.5 & $300(23)$ \\
0.5\% "BULBA" solution & 10 & $324(33)$ \\
\hline
\end{tabular}

Table 4. The influence of different preparations, fertilizers and benz(a)pyrene on the crop capacity of "Irtysh" potato brand using the method the method of top dressing (spraying). The plants (spraying) in bud-formation period.

\begin{tabular}{cccc}
\hline Fertilizer & Fertilizer concentration & Concentration of B(a)P, $\mathbf{n g} / \mathbf{d m} \mathbf{m}^{3} \mathbf{H a r v e s t , ~} \mathbf{c} \mathbf{h}$ (increase, $\left.\mathbf{\%}\right)$ \\
\hline Without spraying (check) & none & none & $94(0)$ \\
Water spraying (check) & none & none & $107(0)$ \\
"GUMAT + 7" & $0.03 \%$, solution, $0.5 \mathrm{dm}^{3} / \mathrm{m}^{2}$ & 3.75 & $150(40)$ \\
"BULBA" & $0.5 \%$, solution, $1.0 \mathrm{dm}^{3} / \mathrm{m}^{2}$ & 7.5 & $158(48)$ \\
"GUMAT + 7" ("GUMEL") & $0.03 \%$, solution, $1.0 \mathrm{dm}^{3} / \mathrm{m}^{2}$ & 10 & $156(46)$ \\
"GUMAT" & $0.03 \%$, solution, $4.0 \mathrm{dm}^{3} / \mathrm{m}^{2}$ & 60 & $154(44)$ \\
\hline
\end{tabular}

Table 5. The dependence of efficient growth stimulation and agriculture crop capacity on the concentration of benz(a)pyrene and the methods of plant treatment.

\begin{tabular}{|c|c|c|c|}
\hline \multirow{2}{*}{ Method of plant treatment } & \multirow{2}{*}{$\frac{\text { Preparation-fertilizer }}{*}$} & \multicolumn{2}{|c|}{ B(a)P efficient concentration } \\
\hline & & Whole range & Optimal \\
\hline Preplant seed treatment Potato tubers of "Volzhanka" brand & "GUMAT" & From 50 to $200 \mathrm{ng} / \mathrm{dm}^{3}$ & From 150 to $200 \mathrm{ng} / \mathrm{dm}^{3}$ \\
\hline $\begin{array}{l}\text { Top dressing (spraying the top part of the plant) } \\
\text { 1) Carrot of "Nantskaya" brand } \\
\text { 2) Potato of "Nevsky" brand } \\
\text { 3) Potato of "Irtysh" brand }\end{array}$ & $\begin{array}{l}\text { "GUMAT" } \\
\text { "GUMAT + 7" } \\
\text { "GUMEL" } \\
\text { "GUMAT-80" } \\
\text { "BULBA" }\end{array}$ & $\begin{array}{l}\text { From } 1.3 \text { to } 37.5 \mathrm{ng} / \mathrm{dm}^{3} \\
\text { From } 0.9 \text { to } 10 \mathrm{ng} / \mathrm{dm}^{3} \\
\text { From } 3.75 \text { to } 60 \mathrm{ng} / \mathrm{dm}^{3}\end{array}$ & From 3.0 to $10 \mathrm{ng} / \mathrm{dm}^{3}$ \\
\hline $\begin{array}{l}\text { Dressing under roots (ground application) } \\
\text { 4) Wheat (roots growth) } \\
\text { 5) Pea (roots growth) } \\
\text { 6) Vegetable cell growth }\end{array}$ & "GUMAT" & $\begin{array}{l}\text { From } 0.05 \text { to } 0.5 \mathrm{ng} / \mathrm{dm}^{3} \\
\text { From } 0.05 \text { to } 0.5 \mathrm{ng} / \mathrm{dm}^{3} \\
\text { From } 0.05 \text { to } 0.5 \mathrm{ng} / \mathrm{dm}^{3}\end{array}$ & From 0.1 to $0.3 \mathrm{ng} / \mathrm{dm}^{3}$ \\
\hline
\end{tabular}

*The content of benz(a)pyrene in the preparations-fertilizers is given in Table 1.

Table 6. Calculation preparation quantity of "Irkutsk humates" to prepare process solution with optimal ranges of benz(a)pyrene concentration.

\begin{tabular}{|c|c|c|c|}
\hline \multirow{2}{*}{$\underset{*}{\text { Preparation-fertilizer }}$} & \multicolumn{3}{|c|}{ Preparation-fertilizer quantity $\left(\mathrm{g} / \mathrm{dm}^{3}\right)$ to preparer $\mathrm{B}(\mathrm{a})$ P optimal concentration } \\
\hline & $\begin{array}{l}150-200 \mathrm{ng} / \mathrm{dm}^{3} \\
\text { (preplant seed treatment) }\end{array}$ & $\begin{array}{l}\quad 0.1-0.3 \mathrm{ng} / \mathrm{dm}^{3} \\
\text { (under the roots treatment) }\end{array}$ & $\begin{array}{l}3-10 \mathrm{ng} / \mathrm{dm}^{3} \\
\text { (top dressing) }\end{array}$ \\
\hline Fertilizer on the basis of humic acids "GUMAT" & $3.0-4.0$ & $0.002-0$ & $0060.06-0.2$ \\
\hline $\begin{array}{l}\text { Fertilizer on the basis of humic acids } \\
\text { with microelements "GUMAT+7" }\end{array}$ & $6.0-8.0$ & $40.004-0.01$ & $0.12-0.2$ \\
\hline Microfertilizer "BULBA" & $75-100$ & $0.05-0.15$ & $1.5-5.0$ \\
\hline Microfertilizer "ZOLUSHKA" & $25-33$ & $0.02-0.05$ & $0.5-1.7$ \\
\hline $\begin{array}{l}\text { Complex organic and mineral fertilizer } \\
\text { "GUMAT-UNIVERSAL" }\end{array}$ & $13-17$ & $0.008-0.025$ & $0.25-0.83$ \\
\hline
\end{tabular}

*The content of benz(a)pyrene in the preparations-fertilizers is given in Table 1. 
quantity used for different ways of agriculture processing are given.

Thus, the got results and known literature data on BaP influence correspondingly in the composition of humates and in the model experiments on growth function of vegetable organisms are similar to a large extent. It makes it possible to speak about having biologically active PAHs in stimulating (or inhibiting) the plant growth depending on rather the substance concentration than its accompanying components. The discovered effects permitted to suggest one way [8] of defining the biological activity and preparation and fertilizers based on the humates testing by screening. It includes $\mathrm{BaP}$ analytical identification and the selection of some optimal acting concentration stimulating the growth and taking into account the content of preparation substance, the conditions of plants processing. The new method differs from the known ones by rapidness, little labour-intensiveness and economic costs, more precision and can be advised for the practical application.

\section{CONCLUSIONS}

1) $\mathrm{BaP}$ concentration in the analyzed samples of the humate preparations and fertilizers on their basis "Irkutsk humates" received on the basis of oxidized brown coal of the Cheremkhovo coal basin vary in the range of $0.3-50$ $\mathrm{mcg} / \mathrm{kg}$. Having such BaP concentration, there is no danger of soil contamination under the conditions of the preparations use.

2) Between $\mathrm{BaP}$ concentration and the salts of humic acids (humates) in "Irkutsk humates" preparations and fertilizers based on them there is a direct positive correlation $\left(r_{x y}=0.952 ; \alpha<0.05\right)$.

3) The observed effects of stimulating the vegetable agriculture growth and crop capacity under the conditions of preplant seed processing, top dressing (spraying) and dressing under the roots (applying to the soil) and additional fertilizing depend on $\mathrm{BaP}$ concentration in the structure of the humate preparations and fertilizers based on them-the maximum effects reveal themselves at the range of optimal concentration, recommended for the practical application subject to the concentration of the stimulant in a preparation and the method of plant processing.

4) The method of defining the biological potency and testing of humates containing preparations and/or fertilizers on their basis and their BaP content by screening as well as the preparing of the effectively operating doses and the conditions of the plants processing are suggested.

\section{REFERENCES}

[1] Butyrin, M.V., Biryukov, V.I. and Puzanov, V.I. (2003) The testing of humates in the Irkutsk region. "GUMAT" Co Ltd, Irkutsk.

[2] Levinsky, B.V. (2000) Everything about humates. "CorPoligraph" Co Ltd., Voronezh.

[3] Ilnitsky, A.P. (1985) The ecological aspects of the circulation of polycyclic aromatic hydrocarbons. Ecology and cancer. Nauk. Dumka, Kiev.

[4] Rovinskiy, F.Y., Teplitskaya, T.A. and Alexeyeva, T.A. (1988) The background monitoring of polycyclic aromatic hydrocarbons. Hydrometeorogical Service of Russia Publ., Leningrad.

[5] Gennadiev, A.N. and Pikovsky, Y.I. (1996) The geochemistry of polycyclic aromatic hydrocarbons in rock and soils. Moscow State University Publ., Moscow.

[6] Sanitary Norms and Regulations 2.3.2.560-96 (1997) Sanitary demands on the quality and safety of the food raw material and food. Food stock and products. State Committee on Sanitary and Epidemiology Surveillance (SCSES) of Russia, Moscow.

[7] Belykh, L.I. and Ryabchikova, I.A. (2008) The methodology of defining the mass concentration of benz(a)pyrene in the trials of vegetable materials using the method of low-temperature luminescence. The certificate of assessment MVI No 224.11.04.019/2008. The Ural Institute of Metrology Publ., Ekaterinburg.

[8] Belykh, L.I., Ryabchikova, I.A., Dodonova, N.E. and Timofeyeva, S.S. (2009) The method of biological potency identification and testing of humates containing preparations and/or fertilizers on their basis and the method of plants biochemical activity increasing (options). Patent No. 2375335 RF, MPK C05F 11/00. 